\title{
In vitro propagation of Notocactus magnificus
}

\author{
Lígia Aíra de Medeiros, Roberval Cássia Salvador de Ribeiro, Luiz Antônio Gallo*, \\ Enio Tiago de Oliveira \& Maria Esmeralda Soares Payão Demattê \\ Escola Superior de Agricultura "Luiz de Queiroz", University of Sao Paulo, Piracicaba, SP, Brazil (*requests \\ for offprints: E-mail: luagallo@esalq.usp.br)
}

Received 10 June 2005; accepted in revised form 10 August 2005

Key words: Cactaceae, callus proliferation, Eriocactus magnificus, Notocactus magnificus, organogenesis, plant regeneration, plant tissue culture

\begin{abstract}
Most commercially grown cacti can be easily propagated by seed and/or cuttings. A group of rare and endangered species does not fit into this category and is therefore a good candidate for in vitro propagation productions as a tool to overcome habitat and plant-destruction. The number of rare and endangered species of Cacti goes into about 100. Many show a low production and germination of seeds and plantlets are prone to damping-off, making the in vitro propagation a feasible alternative for the multiplication and conservation of their germplasm. The aim of the present investigation is to establish a protocol for the in vitro culture and plant regeneration of Notocactus magnificus, the blue cactus, a highly ornamental species, native to Brazil. The surface sterilization of the explants was achieved with immersion for $10 \mathrm{~min}$ in sodium hypochlorite solution for either seeds $(0.25 \% \mathrm{v} / \mathrm{v})$ or ribs segments $(1 \%$ $\mathrm{v} / \mathrm{v})$. Callus formation was observed when explants were cultured on MS medium supplemented with sucrose at $2 \%(\mathrm{w} / \mathrm{v}), 2,4$-dichlorophenoxyacetic acid $0.5 \mu \mathrm{M}$, benzylaminopurine $4.4 \mu \mathrm{M}$, thiamine $\mathrm{HCl}$ $0.4 \mathrm{mg}^{-1}$ and i-inositol $100 \mathrm{mg}^{-1}$. The regeneration of shoots was carried out on MS medium supplemented with either different concentrations of benzylaminopurine and 1-naphthaleneacetic acid, or kinetin and indole-3-acetic acid. The highest number of shoots occurred when MS medium was supplemented with benzylaminopurine $22.2 \mu \mathrm{M}$, sucrose $3 \%(\mathrm{w} / \mathrm{v})$ and agar $0,6 \%(\mathrm{w} / \mathrm{v})$. In vitro spontaneous rooting of shoots was observed after eight months under culture on MS medium. Only in vitro rooted shoots developed into normal plants under glasshouse culture conditions. This in vitro protocol should be useful for the conservation as well as mass propagation of Notocactus magnificus.
\end{abstract}

Abbreviations: BAP - benzylaminopurine; 2,4-D - 2,4-dichlorophenoxyacetic acid; IAA - indole-3-acetic acid; Kinetin - 6-furfurylaminopurine; $2 \mathrm{iP}-\mathrm{N}^{6}-\left(\Delta^{2}\right.$-isopentenyl) adenine; IBA - indole-3-butyric acid; MS - Murashige and Skoog medium; NAA - 1-naphthaleneacetic acid

\section{Introduction}

The Cactaceae family thrives from Canada through to the extreme south of Argentina (Rizzini, 1987). Most species are found growing in arid or semi-arid regions, whilst some can be seen in jungles and tropical rainforests. In Brazil there are 32 indigenous genus, comprising 160 species, Bahia State being the dispersion center
(Seixas, 2001). According to Moura (1979) every Cactaceae species is at risk of disappearing from its natural habitat.

As cacti seeds are frequently difficult to be obtained (Mauseth, 1977) and plantlets are reported to be susceptible to damping-off (Mauseth, 1979; Ault and Blackmon, 1987), the in vitro propagation is a feasible alternative for the rapid multiplication and maintenance of germplasm (Smith et al., 1991; 
Johnson and Emino, 1979), therefore lowering the danger of extinction for many Cactaceae.

The surface sterilisation of cacti is extremely important because the spikes and hairs normally found in such plants host a large variety of microorganisms. Several chemicals have been reported for such procedure, such as sodium hypochlorite (Johnson and Emino, 1979), chloramine B (Vyskot and Jara, 1984) and calcium hypochlorite (Escobar et al., 1986).

Johnson and Emino (1979), working with thornless Mammilaria elongata tubers found that the largest amount of friable calli was achieved by Murashige and Skoog (1962) high salts supplemented with Murashige et al. (1974) organic mixture adjusted to $\mathrm{pH} 5.6$ using $2-10 \mathrm{mg} \mathrm{l}^{-1}$ 2,4-D and 1-2 $\mathrm{mg} \mathrm{l}^{-1}$ kinetin or 2iP. Shoot induction was optimized with the addition of $10 \mathrm{mg}^{-1}$ $2 \mathrm{iP}$ and $1 \mathrm{mg} \mathrm{l}^{-1} \mathrm{IAA}$, while roots formed by culturing on media containing $60 \mathrm{mg}^{-1} \mathrm{NAA}$ or IBA with complementary levels of $1-2 \mathrm{mg}^{-1}$ kinetin or $2 \mathrm{iP}$.

According to Clayton et al. (1990), many cacti produce an excess of auxin under in vitro culture conditions, stimulating the callus production, a negative for micropropagation. Opuntia amyclaea was reported to have rooted on medium without the supply of exogenous auxin (Escobar et al., 1986). Ault and Blackmon (1987) also observed spontaneous rooting and $90 \%$ of shooting in Ferocactus acanthodes on medium lacking auxin. The highest concentrations of cytokinin is the most adverse in subsequent rooting; this adverse effect can be minimized by a passage on hormone-free medium to help to reduce cytokinin carry over, before application of specialized treatments (Hubstenberger et al., 1992).

The aim of the present work was to establish a reliable protocol for the in vitro propagation of Notocactus magnificus.

\section{Material and methods}

\section{Plant material and explant sources}

Notocactus magnificus (Ritter) Krainz seeds and 2 years old potted plants were supplied by Cactos Hino, Jundiaí, SP, Brazil. Rib segments of approximately $1 \mathrm{~cm}^{2}$ from the potted plants (Figure 1e, f) or hypocotyls of in vitro germinated seeds were the explant sources. Rib explants were surface sterilised using sodium hypochlorite at $0.25,0.5$ and $1 \%$ (v/v) for 10 or $20 \mathrm{~min}$., while seeds were efficiently surface sterilised with sodium hypochlorite at $0.25(\mathrm{v} / \mathrm{v})$ for $10 \mathrm{~min}$. Both ribs and seeds were subsequently washed six times with sterile distilled water.

\section{Basal media and culture conditions}

Murashige and Skoog (1962) basal medium was used in all experiments. Glass cultures vessels with 20 diameter $\times 10 \mathrm{~cm}$ high using a plastic cap, were maintained at $25 \pm 2{ }^{\circ} \mathrm{C}$ with 14 -h light/10-h dark photoperiod at $47 \mu \mathrm{mol} \mathrm{m} \mathrm{m}^{-2} \mathrm{~s}^{-1}$ DFFF. Plants in the glasshouse were cultured under $80 \%$ humidity, $70 \%$ shading, $25 \pm 5{ }^{\circ} \mathrm{C}$ and natural daylength.

\section{Seed germination}

Seeds were efficiently surface sterilized with sodium hypochlorite at $0.25(\mathrm{v} / \mathrm{v})$ for $10 \mathrm{~min}$, followed by six washes in sterile distilled water. After this procedure they were transferred under sterile conditions to test tubes containing MS medium with $2 \%(\mathrm{w} / \mathrm{v})$ sucrose. As the in vitro germination rate was very low (below 13\%) a further test was carried out in a germination chamber, using Gerbox with 25 seeds on moist filter paper at alternate temperatures $\left(20-30{ }^{\circ} \mathrm{C}\right)$, under constant illumination $\left(15 \mu \mathrm{mol} \mathrm{m}{ }^{-2} \mathrm{~s}^{-2}\right.$ DFFF), 4 replicates and 4 assessment times: 5, 10,15 and 22 days after the beginning of the test.

\section{Callus formation}

Hypocotyls of in vitro germinated seeds or rib segments were cultured on MS medium supplemented with thiamine $\mathrm{HCl} 0.4 \mathrm{mg} \mathrm{l}^{-1}$, i-inositol $100 \mathrm{mg} \mathrm{l}^{-1}$, sucrose $2 \%(\mathrm{w} / \mathrm{v})$, BAP $4.4 \mu \mathrm{M}$ and 2,4-D $0.5 \mu \mathrm{M}, \mathrm{pH}$ at 5.7 (Smith et al., 1991). Callus formation was carried out in a culture room at $25 \pm 2{ }^{\circ} \mathrm{C}$ in the dark.

\section{Shoot differentiation}

Calli (6-8 $\mathrm{mm}$ ) were transferred onto MS medium supplemented with three different combinations of growth regulators, sucrose and gelling agent. The first consisted of $\operatorname{BAP}(0,2.2,8.9$ or $22.2 \mu \mathrm{M})$ with 


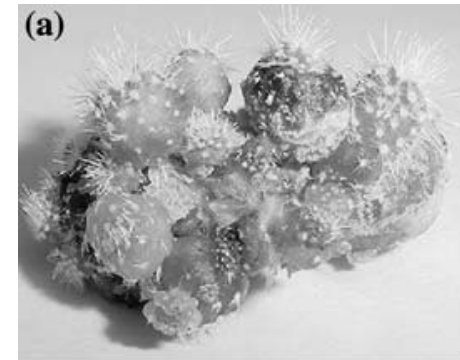

(d)

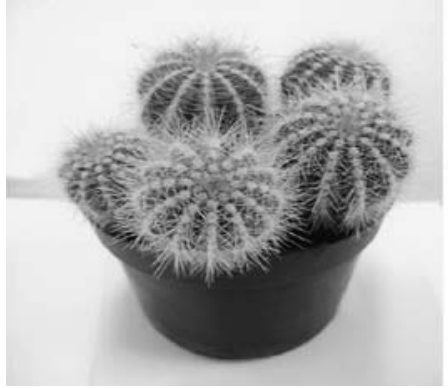

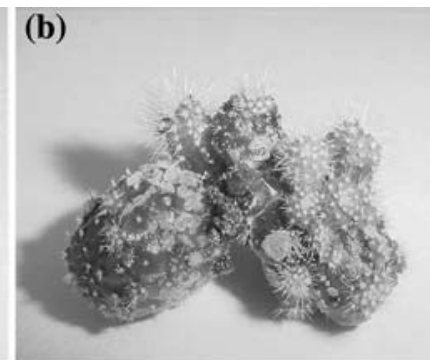

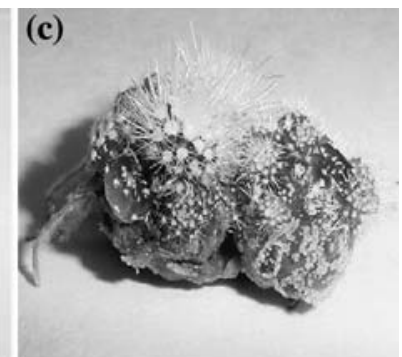

(e)
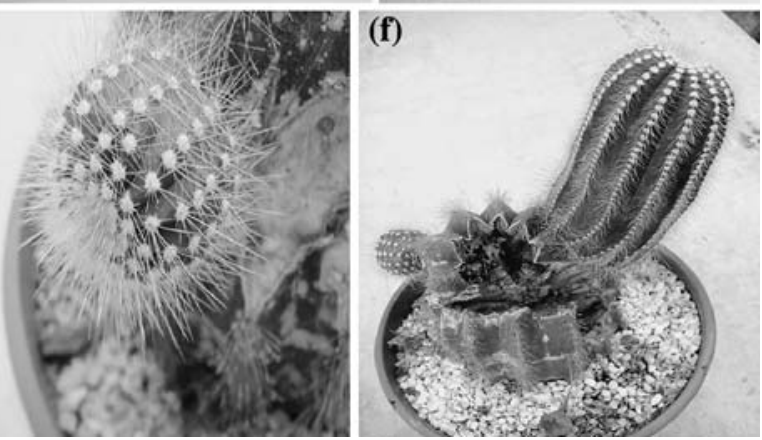

Figure 1. Several phases of in vitro micropropagation of Noctocactus magnificus. $(a, b)$ Represents the shoot formation of several shoots/callus after 4 weeks on MS medium supplemented with BAP $22.2 \mu \mathrm{M}$, sucrose $3 \%$ (w/v), made semi-solid with agar $0.6 \%$ $(\mathrm{w} / \mathrm{v}) ;(c)$ Rooting of callus after 6 months in culture growing on hormone free media. (d) Six months old plants acclimated obtained from in vitro culture. $(e, f)$ The original plant from where the explants were obtained.

NAA $(0,2.7,10.7$ or $26.9 \mu \mathrm{M})$ as well sucrose $(3 \%$ $\mathrm{w} / \mathrm{v})$ and agar $(0.6 \% \mathrm{w} / \mathrm{v})$. The second one was comprised of kinetin $(0,4.6,9.3$ or $23.2 \mu \mathrm{M})$ with IAA $(0,2.9$ or $5.7 \mu \mathrm{M})$, sucrose $(2 \% \mathrm{w} / \mathrm{v})$ and Phytagel $(0.2 \% \mathrm{w} / \mathrm{v})$. The third medium was supplemented with BAP (0, 4.4, 22.2 and 44.4 $\mu \mathrm{M})$, sucrose $(2 \% \mathrm{w} / \mathrm{v})$, Phytagel $(0.2 \% \mathrm{w} / \mathrm{v})$ and activated charcoal $\left(500 \mathrm{mg}^{-1}\right)$ in order to avoid putative oxidation.

Shoot differentiation and elongation were carried out under $25 \pm 2{ }^{\circ} \mathrm{C}$ with 14 -h light/10-h dark photoperiod at $47 \mu \mathrm{mol} \mathrm{m} \mathrm{m}^{-2} \mathrm{~s}^{-1}$ DFFF.

\section{Root formation}

The in vitro rooting was carried out on MS medium containing $(2 \% \mathrm{w} / \mathrm{v})$ sucrose and Phytagel $(0.2 \% \mathrm{w} / \mathrm{v})$.

\section{Hardening}

Ex vitro culture was carried out in a glasshouse under $70 \%$ shading and $80 \%$ humidity. Rooted shoots were washed to remove culture medium and placed on multicell plastic trays (24
$6 \times 6 \times 6 \mathrm{~cm}^{2}$ cells/tray), 3 shoots/cell, filled with either $100 \%$ Plantmax compost (Eucatex, Jundiai, SP), $100 \%$ washed sand or $50 \%$ Plantmax and $50 \%$ washed sand.

\section{Results and discussion}

\section{Seed germination}

In vitro germinated seeds showed an average germination of $13 \%$. The germination after 22 days in germination chamber achieved a figure of $26 \%$. The lower percentage of germination under aseptic condition may be due to factors such as low seed viability, inadequate osmotic potential of the medium or high humidity. Seixas (2001) obtained a germination of $2.05 \%$ for seeds of N. magnificus on seven different composts, well inferior figure to the $70 \%$ observed when seeds were cultured for 18 days in a germination chamber under illumination and alternate temperatures $\left(20-30{ }^{\circ} \mathrm{C}\right)$, identical to those used in the present investigation, except for the use of sand instead of filter paper. 


\section{Surface sterilisation of explants}

Due to the large amount of thorns observed on the stems of $N$. magnificus, the surface sterilization was only efficient when rib explants were submerged in sodium hypochlorite at $1 \%(\mathrm{v} / \mathrm{v})$ solution for $10 \mathrm{~min}$. This result complies with Smith et al. (1991), working with Coryphanta macromeris.

\section{Callus formation}

The protocol used by Smith et al. (1991) was also efficient for the formation and proliferation of N. magnificus pale (lacking chlorophyll) and compact calli.

\section{Shoot differentiation and ellongation}

Some shoot proliferation of $N$. magnificus occurred in the dark after 2-4 months on the same medium used for callus formation. The resulting shoots were subsequently transferred to the light at $47 \mu \mathrm{mol} \mathrm{m} \mathrm{m}^{-2} \mathrm{~s}^{-1}$ DFFF onto MS medium supplemented with BAP $4.4 \mu \mathrm{M}$ and $2 \%$ sucrose $(\mathrm{w} / \mathrm{v})$, made semi-solid with Phytagel $0.2 \%$ $(\mathrm{w} / \mathrm{v})$, resulting in several shoots per callus, which after excision gave rise to an average of 6 shoots.

A better regeneration rate, though, was observed when calli were subcultured onto fresh callus inducing medium after 4 weeks and finally transferred onto shoot regeneration medium after a total of 8 weeks in culture. An average of 6 shoots/callus were observed after 4 weeks on MS medium supplemented with BAP $22.2 \mu \mathrm{M}$, sucrose $3 \%(\mathrm{w} / \mathrm{v})$, made semi-solid with agar $0.6 \%(\mathrm{w} / \mathrm{v})$. Similar results (5 shoots/callus) were observed when calli were transferred onto MS medium supplemented with kinetin $4.6 \mu \mathrm{M}$, IAA $2.9 \mu \mathrm{M}$, sucrose $2 \%(\mathrm{w} / \mathrm{v})$, made semi-solid with Phytagel $0.2 \%(\mathrm{w} / \mathrm{v})$ but the rising of shoots occurred only after 12 weeks in culture (Figure $1 \mathrm{a}, \mathrm{b}$ ).

In every case, the resulting shoots were transferred onto MS medium lacking growth regulators, but containing sucrose $2 \% \quad(\mathrm{w} / \mathrm{v})$ and Phytagel $0.2 \%(\mathrm{w} / \mathrm{v})$ for further development.

\section{Root formation}

As also reported by Escobar et al. (1986) for O. amyclaea and Ault and Blackmon (1987) for
$F$. acanthodes, in vitro rooting occurred spontaneously. After 6 months in culture shoots showed a darker shade of green, typical shape and cuticule formation. Efficient rooting occurred after 6 months in culture. On the completion of 8 months in culture $45 \%$ of the shoots showed roots (Figure 1c).

\section{Hardening}

Non-rooted shoots did not grow under glasshouse conditions, in contrast with the $90 \%$ rooting reported by Ault and Blackmon (1987) for F. acanthodes. Only $20 \%$ of previously rooted shoots survived the glasshouse conditions when cultured on $50 \%$ sand and $50 \%$ compost. Rooted shoots kept on $100 \%$ compost showed a loss of $78 \%$ due to diseases stimulated by higher humidity, while those cultured on $100 \%$ sand died because of low water retention (Figure 1d).

\section{Conclusion}

The protocol herein described is efficient for the in vitro multiplication of $N$. magnificus through indirect organogenesis enabling the conservation and propagation of this species. Further studies need to be carried out in order to improve rooting and acclimatization.

\section{Acknowledgements}

The authors would like to thank the financial support from Conselho Nacional de Desenvolvimento Científico e Tecnológico (CNPq/PIBIC) and Cactus Hino, Jundiaí, SP, Brazil.

\section{References}

Ault JR \& Blackmon WJ (1987) In vitro propagation of Ferocactus acanthodes (Cactaceae). HortScience 22: 126-127

Clayton PW, Hubstenberger JF, Phillips GC \& Butler-Nance S (1990) Micropropagation of members of the Cactaceae subtribe Cactinae. J. Am. Soc. Horticult. Sci. 115: 337-343

Escobar HA, Villalobos VM \& Villegas A (1986) Opuntia micropropagation by axillary proliferation. Plant Cell Tissue Org. Cult. 7: 269-277

Hubstenberger JF, Clayton PW \& Phillips GC (1992) Micropropagation of cacti (Cactaceae). In: Bajaj YPS (ed) 
Biotechnology in Agriculture and Forestry Vol. 204 (pp 4968). Springer-Verlag, Berlin

Johnson JL \& Emino ER (1979) In vitro propagation of Mammillaria elongata. HortScience 14: 605-606

Mauseth JD (1979) A new method for the propagation of cacti: sterile culture of axillary buds. Cact. Succ. J. (US) 51: 186-187

Mauseth JD (1977) Cactus tissue culture: a potencial method of propagation. Cact. Succ. J. (US) 49: 80-81

Moura V (1979) Natureza Violentada: flora e fauna agredidas . Agropecuária, Porto Alegre

Murashige T, Serpa M \& Jones JB (1974) Clonal multiplication of Gerbera through tissue culture. HortScience 9: 175-180
Murashige T \& Skoog F (1962) A revised medium for rapid growth and biossays with tobacco tissue cultures. Physiol. Plant. 15: 473-497

Rizzini CT (1987) Cactáceas: os segredos da sobrevivência. Ciência Hoje 30: 30-40

Seixas ES (2001) Emergência e desenvolvimento inicial de plântulas de Cactaceae em diferentes substratos com e sem adubação. M.Sc. Thesis, State University of Sao Paulo

Smith RH, Burdick PJ, Anthony J \& Reilley AA (1991) In vitro propagation of Coryphanta macromeris. HortScience 26: 315-317

Vyskot B \& Jara Z (1984) Clonal propagation of cacti through axillary buds in vitro. J. Horticult. Sci. 59: 449-452 